
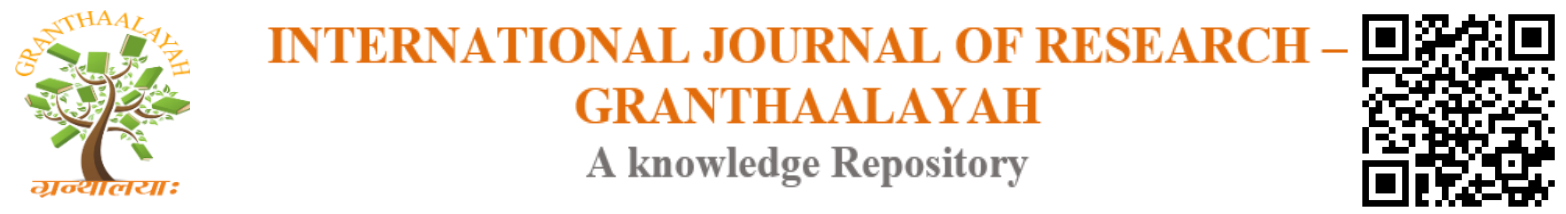

Science

\title{
EFFECTS OF MECHANICALLY STABILIZED GRADED ASSORTED COARSE-GRAINED SOILS IN THE PERFORMANCE OF UNPAVED ROAD: A CASE STUDY IN GOFFA ZONE, SAWLA AREA
}

\author{
Edire Erko Esho ${ }^{* 1}$, Prof. Emer Tucay Quezon ${ }^{* 2}$, Democracy Dila ${ }^{3}$ \\ ${ }^{1}$ Road \& Transport Engineering Stream, Arba Minch Institute of Technology, Ethiopia \\ ${ }^{2}$ Civil \& Construction Engineering and Management Streams, Institute of Technology, Ambo \\ University, P.O Box. 019, Ambo, Oromia Region, Ethiopia \\ ${ }^{3}$ Faculty of Civil Engineering Department, Arba Minch Institute of Technology, Ethiopia
}

\begin{abstract}
Road network development in Ethiopia is booming, radiating from Addis Ababa towards NorthSouth directions, and East-West directions, due to the good economic growth of the country. However, there are challenges always facing by the pavement designers, and materials engineers for every road project, specifically the unpaved roads in Goffa Zone. It was because, most parts of the existing unpaved road sections within the study area are heavily damaged, and lack of proper maintenance. The source of good quality of sub-base course materials limited and becoming depleted. It is for this reason that the research study focused on the investigation of the effects of mechanically stabilized graded assorted coarse-grained soils. Disturbed and undisturbed samples from different quarry sites were considered and tested in the laboratory. Laboratory test for each location performed, and the results served as control values of the engineering properties of natural soils. The Disturbed samples tested for Gradation, Atterberg's Liquid Limit Tests, and Compaction, while, the undisturbed sample tested for the CBR strength, using ASTM manual. The results of the assorted materials for the sub-base course was analyzed and compared with the AASHTO and ERA Standard Specifications.
\end{abstract}

Keywords: Graded Assorted Natural Gravel; Index Properties; Mechanical Stabilization; Soaked CBR Value; Unpaved Road.

Cite This Article: Edire Erko Esho, Prof. Emer Tucay Quezon, and Democracy Dila. (2019). "EFFECTS OF MECHANICALLY STABILIZED GRADED ASSORTED COARSE-GRAINED SOILS IN THE PERFORMANCE OF UNPAVED ROAD: A CASE STUDY IN GOFFA ZONE, SAWLA AREA." International Journal of Research - Granthaalayah, 7(8), 133-156. https://doi.org/10.29121/granthaalayah.v7.i8.2019.647.

\section{Introduction}

Unpaved roads composed mostly in the road network of developing countries, and some in highly developed countries such as the United States [1]. The future development of most of these 
countries is fundamentally dependent on the existence of sufficient road networks. And roads often constitute around $70 \%$ to $90 \%$ of the road network in developing countries, while earth roads and tracks dominate the undesignated network [2]. The Universal Rural Road Access Program (URRAP) aimed at connecting all kebeles to the nearby higher-class road using all-weather pavement solutions [3].

Unpaved roads generally carry local traffic between feeder roads and villages to provide links between paved collector roads. In many rural areas, much of the local road system composed of unpaved/gravel surface which requires proper routine maintenance to keep it open. The top layer of gravel on these roads must be shaped, compacted, and smoothed to ensure a good riding surface and to allow runoff to move quickly from the road surface to established drainage ways [4]. Gravel and earth roads in Ethiopia, require a mechanism to which the sub-base of the pavement provided sufficient service about strength capacity and resisting deformation of the surface due to moving traffic loads. Therefore, it needs to apply stabilization methods to strengthen and increase the durability of the unpaved road.

The concept of mechanical stabilization is to blend the available natural gravel so that, when properly compacted, it will provide the desired stability in subject road sections areas. Stabilization aims at improving the strength and increasing resistance to softening of water through bonding the soil particles together, waterproofing the layers. Fine-grained materials are the easiest to stabilize due to their large surface area about their particle diameter while blending fine materials with available natural gravel trial combinations will be followed based on the mechanical analysis. Relative to this, the researcher performed calculations to determine the gradation of the combined materials and the proportion of each component so that the gradation of the combination could lie within the specified limit. Proper treatment of problematic soils and the preparation of the foundation are the important factors to ensure a long-lasting pavement structure that will not require excessive maintenance in the future. This treatment can be done by stabilizing the soil to form a construction layer or a long-term subsurface and sub-base layers capable of carrying Axle loads $[5,6]$.

The amount and type of fine grains in a sub-base material are very important in assessing the properties of gravel material, and it would be classified using the AASHTO soil classification system (AASHTO M145). This classification system will identify granular materials such as sand, gravel, and stone fragments based upon the gradation and Atterberg's Liquid limits tests. In order to achieve the research objectives, all the requirements starting from site observations, samples to be collected, and relevant laboratory tests and analysis of results to be obtained from input data were undertaken.

To form the unpaved road with recommended strength, it requires proper proportioning of the layers and the right selections of materials to ensure a long-lasting pavement structure that does not require excessive maintenance in the future. Hence, field and laboratory investigations on the engineering properties of the natural gravels from different sources would be conducted in order to come up with the appropriate ratios meeting the minimum requirements based on the Standard Specifications, that could be used for sub-base layer, specifically, within the study area along Sawla-Mela Road Section. 


\subsection{Statement of the Problem}

Several problems may occur in constructing unpaved roads due to budget constraint. It could be noted that unpaved road requires long-term maintenance, and their condition may be significantly affected by excessive defects and deficiencies caused by traffic volumes. Typical defects which may affect gravel roads are dusty, potholes, stoniness, corrugations, ruts, cracks, raveling, erosion, slipperiness, impassibility, and loss by wearing course material [7]. There are different reasons why the stabilization of gravel was required, lack of good quality materials on the project site. There may be another reason that when using stabilization could be of cost savings in the long runs. The pavement engineer is trying to build a problem-free pavement that may last for its intended design life within the optimum economic cost. The cost savings associated with stabilization may take some forms, including reduced construction costs, reduction of maintenance costs of the entire life of the pavement, or life extension of the normal condition of pavement [8].

In Ethiopia, the source of suitable materials for road construction may become increasingly difficult as conventional high-quality materials are depleted in many areas. The costs of hauling or transporting materials from a long distance may also increase, however, in order to minimize the problem associated with the pavement life, an affordable stabilization method for natural gravel, as a sub-base material for the unpaved road has to be performed for locally available materials. From previous related studies, a different mechanism introduced to stabilize the soil to achieve the required strength, such as lime, cement, calcium, fly ash both individually and mixing but less attention was given to locally available natural gravel materials within Goffa Zone. It was observed nowadays, some sections of the unpaved road are severely damaged along the stretch of Sawla-Mela-Galma Road and gravel roads within the Sawla town, of which totally affecting the local motorists and commuters.

It was at this juncture that this study conducted to identify sources of natural gravels possible for blending in order to obtain an optimum ratio for unpaved sub-base course construction. However, it may be considered that some areas for use in this study comprising natural gravel materials that may constitute low performance on sub-base layer without blending in several proportions, but once, it would be blended with another source, may indicate good quality of materials.

\subsection{Research Questions}

The research questions that this research study sought to answer; are as follows:

1) Where are the available sources of natural gravel materials suitable for blending to use for sub-base course within Goffa Zone?

2) What are the physical and mechanical properties of natural gravel material by mechanical stabilization from quarry sites?

3) What is the optimum mix ratio of blending different sources of natural gravel for sub-base material?

4) Which source of natural gravel materials within Goffa Zone that can meet the minimum requirements for the sub-base course of unpaved road construction? 


\subsection{Objectives of the Study}

\subsubsection{General Objective}

The main goal of the study is to determine the effects of mechanically stabilized graded assorted coarse-grained soils in the performance of unpaved road along Goffa Zone.

\subsubsection{Specific Objectives}

- To identify the sources of different natural gravel materials suitable for blending to use for sub-base course material.

- To determine and discuss the engineering properties of natural gravel material by mechanical stabilization from the different sources.

- To determine the optimum mix ratio of blending assorted natural gravel from different sources for sub-base course material.

- To suggest the natural gravel materials within Goffa Zone that can meet the minimum requirements for the sub-base course of unpaved road construction.

\section{Study Area, Materials, and Methods}

\subsection{Study Area}

Sawla town is located $553 \mathrm{kms}$ South-West of Addis Ababa, and it is a zonal capital city Goffa zone of the Southern Regional State of Government. According to data obtained from the Ethiopian Meteorological Agency, Yela Sawla Station indicated that the Goffa area has three seasonal variations;

- Kiremt season (June-September); with a maximum and minimum temperature of $30.13^{\circ} \mathrm{C}$ and $17.20^{\circ} \mathrm{c}$ respectively. The rainfall ranges from Bega $213 \mathrm{~mm}$ to Kiremt $819 \mathrm{~mm}$.

- Bega season (October-January); with maximum and minimum temperatures of $35.63^{\circ} \mathrm{c}$ and $12.73^{\circ} \mathrm{c}$.

- Belg season (February-May); with maximum and minimum temperatures of $26.7^{\circ} \mathrm{c}$ and $12.5^{\circ} \mathrm{c}$.

The selected materials for this research were taken from quarry sites within Sawla area, namely: Duza, Suka and Mela, which are located at 2, 4 \& 20 kilometers away from Sawla Town, respectively.
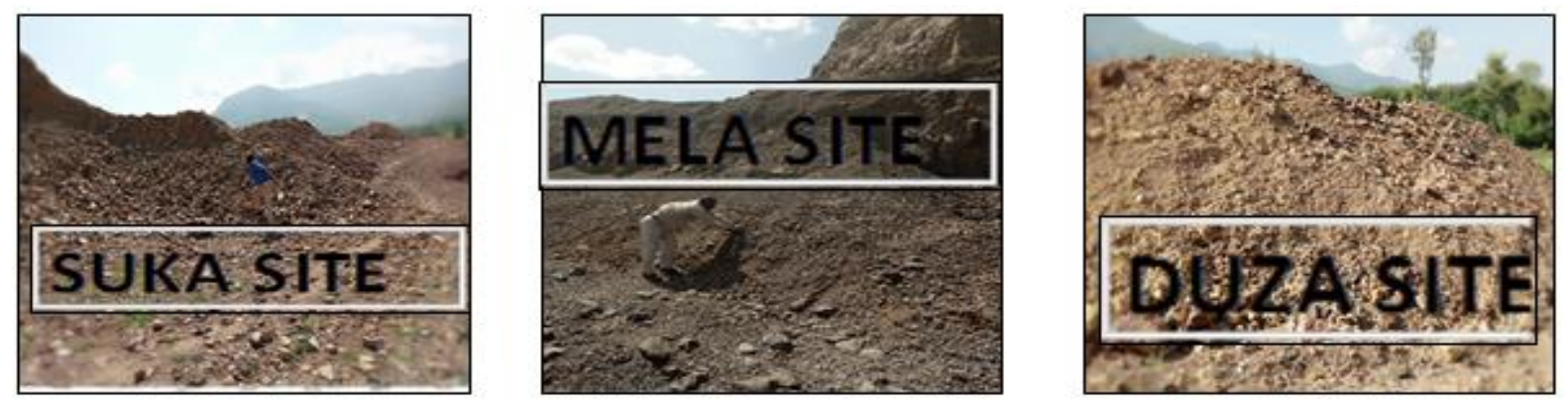

Figure 1: Source of materials from three quarry sites for the laboratory investigation 


\subsection{Study Procedures}

Relevant literature reviewed on the improvement of engineering properties of natural gravel materials by mechanical stabilization method as a sub-base material for the unpaved road which includes: Articles, reference books, research papers, class lecture notes, project specifications, and standard specifications like ERA, AASHTO, and ASTM. In the laboratory, materials were tested with and without blending and compared with the standard specifications.

\subsubsection{Sampling Technique}

A representative sampling technique used by selecting particular materials to make sure that the parameters possessed certain characteristics when applied for this research study. It was projected to be normally targeted at particular geotechnical parameters.

\subsubsection{Method for Blending Aggregates}

Analytical procedures were available to find out the optimum combination of aggregate materials, but the "Trial and Error Method" guided by a certain amount of reasoning was the most practical procedure to determine a satisfactory combination and the one that was demonstrated. In order to improve the weak parameters, after blending the materials from two quarry sites, Laboratory test was undertaken. Estimation of blending ratio for the mechanical stabilization conducted by trial and error process. Gradation and plastic properties were the basic parameters in blending [26].

$a=100 S B(P-P B) /[S B(P-P B)-S A(P-P A)$

$b=100-a$

$a=$ amount of soil from Suka site in the blended mix $(\%)$

$b=$ amount of soil from Mela site in the Blended mix (\%)

$\mathrm{p}=$ desired PI of the blended mix

$P A=$ PI of soil from Suka site

$P B=$ PI of soil from Mela site

$S A=$ amount of soil Suka site passing the 425-micron sieve (\%)

$S B=$ amount of soil Mela site passing the 425-micron sieve (\%).

Using the above formula (1) and (2) without the amount of soil A blended mix can be computed, then followed by the amount of soil $\mathrm{B}$ in the blending mix of ' $\mathrm{b}$ ' while the passing percentage of each standard sieve multiple by getting a percentage of ' $a$ ' and divided by $100=\mathrm{x}$. The same procedure to get the passing percentage of each standard sieve multiplied by getting the percentage of ' $b$ ' and divided by $100=y$. The sum of expression is derived, such as $(x+y)=s$. The 's' value is compared to ERA standard specifications for use as sub-base materials. Once fulfilling the ERA standard specifications sieve for soil materials as sub-base materials by gradation, other parameters are checked. In Table 1, it showed the blending /mix proportion of trial and error considering the different parameters and its values. 


\subsubsection{Preparation of Specimens}

There were three (3) quarry sites around Sawla Town Administration considered for this research study. However, there were only two, out of three quarry sites in the study area found viable to satisfy or fulfill the Standard specification. The formula used to compute the percent composition of the amount of soil A (Suka site) and the amount of soil B (Mela site).

\subsection{Sampling Technique}

The sampling technique used by selecting particular parameters to make sure that the parameters had certain characteristics when it applied for this research study. It was projected to be normally targeted at particular geotechnical parameters.

\subsection{Study Variables}

Independent variables: The independent variables considered; as follows: CBR, PI (Plasticity index), LAA (Los Angeles Abrasion), Grain size distribution.

Dependent variable: Density of Natural gravel material.

\subsection{Software and Instruments}

The following instruments, materials and software are used for this study:

Sample bags, Meter tape, Sample taking an instrument, laboratory apparatus (Group sieve, Los Angeles machine and ball, CBR machine, Attarberg's Liquid limit device, Compaction mold and rammer (using Modified Proctor Test), Digital Camera for documentation, MS Word and Excel to tabulate and analyze laboratory data.

\subsection{Field Identification}

Identification of soil type in the field was often limited to an estimated extent of texture, color, and plasticity. Such observations performed to get a general understanding of the site and the material sample. Simple visual examinations conducted by carefully examining the soil characteristics which would categorize silt or clayey gravel and fine soils.

\subsection{Data Collection Process}

Three quarry sites selected for the study, and three representative samples extracted from each of these sites by $4 \mathrm{~km}$ to $20 \mathrm{~km}$ difference around Sawla areas, such as Duza-A, Mela-B, and Mela-C quarry sites.

Table 1: Field data sheet

\begin{tabular}{|l|l|l|}
\hline No & Type of test & Size of sample taken from Quarry sites $(\mathbf{K g})$ \\
\hline 1 & Gradation $/$ sieve analysis & 3sites*3samples*15kg $=135 \mathrm{~kg}$ \\
\hline 2 & Abrasion (L.A.A) & 3sites*3samples*15kg $=135 \mathrm{~kg}$ \\
\hline 3 & C.B. R & 3sites*3samples*10kg $=90 \mathrm{~kg}$ \\
\hline 4 & Atterberg's Limit Test, & 3sites*3samples*15kg $=135 \mathrm{~kg}$ \\
\hline 5 & Compaction & 3sites*3samples*20kg $=180 \mathrm{~kg}$ \\
\hline 6 & Direct shear & 3sites*3samples*5kg $=45 \mathrm{~kg}$ \\
\hline
\end{tabular}


For each site, there were six different tests performed. From these tests, the average value recorded as input parameters for the analysis by comparing with the ERA Standard specifications, and AASHTO.

\subsection{Laboratory Tests}

The representative samples gathered during data collection, which was necessary for laboratory activities. These tests performed at Arba Minch University Laboratory, and at the Ethiopia Road Authority, Wolaita Sodo District Office. The tests included: Atterberg's Limits, Grain size Analysis, Compaction Tests, Los Angeles Abrasion Test, and California Bearing Ratio (CBR) Tests. The researchers collected specimens from each quarry site to conduct the required laboratory tests in accordance with AASHTO specification, ASTM, and ERA manual (2002).

Atterberg's limit test: The liquid limits, plasticity limits, and plasticity index test determined in accordance with test method AASHTO T89, T90. Most of the methods for soil identification and classification based on certain physical properties of the soils. The commonly used properties for the classification where the grain size distribution, liquid limit, and plasticity index, of which this research considered these parameters for the experiment.

Compaction Test Method: The test performed the following the AASHTO T-180:-Modified compaction or Modified Proctor Test. This test method used to determine the relationship between the moisture content and density of soil when compacted in a given mold of a given size with a $4.5 \mathrm{~kg}$ hammer dropped from a height of $457 \mathrm{~mm}$. The selected natural gravel materials which are passing19mmsievesize used for this study, and mold with collar attached in five equal layers utilized to provide a total compacted depth $127 \mathrm{~mm}$. Each layer had compacted by 56 uniformly distributed blows from the hammer.

Grain size analysis: This test, Method AASHTO T- 88 was used. In this test method, it was described as a procedure for the quantitative determination of the distribution of particle size in soil by grading requirements based on Standard Technical Specification - 2002.

- The specimen was used for the test obtained from the original sample by riffling, or by subdivision using the cone-and-quarter method.

- The sample was placed on a tray, and it was allowed to dry, preferably overnight, in an oven from $105-110^{\circ} \mathrm{C}$.

- After drying the sample at a constant weight, the whole specimen allowed to cool and is weighted to an accuracy within $0.1 \%$ or less of its total mass.

Los- Angeles abrasion test (LAA); test method ASTM D: C 131 - 03): -The LAA value which was expressed as the percentage of fine passing the $1.18 \mathrm{~mm}, \mathrm{BS}(1.7 \mathrm{~mm}$ ASTM) sieve an estimate of the abrasion resistance of the aggregate.

Los Angeles Abrasion (LAA) test is very widely accepted as a suitable test to assess the hardness of aggregates used in pavement construction. Los Angeles machine and sieves utilized for the test. The oven-dried sample would be sieved through a $1.8 \mathrm{~mm}$ sieve and weighed. The specimen placed in the cylinder machine. And then a rotation of 500 revolutions at a speed of 28 to 30 revolutions per minute was applied. After the desired number of revolutions, the material discharged and 
graded through $1.8 \mathrm{~mm}$ size sieve. The material that was coarser than $1.7 \mathrm{~mm}$ size had to be washed and to be dried in an oven and weighed. The difference in weight between the original sample and final weights of the sample expressed as a percentage of the total weight of the sample and to be recorded as the percentage wear. Apparatus such as Loss Angeles Abrasion machine, sieve $1.18 \mathrm{~mm}$ size, and electric oven used for the experiment.

California bearing ratio (CBR) test: Test Method AASHTO T-180 method and AASHTO T193 were used. The CBR test consisted of the following procedures as a key point to arrive the results of the strength value.

- Compacting a sample at its optimum moisture content

- Applying a surcharge to the sample to represent the estimated thickness of pavement over the sub-base and subgrade materials.

- $\quad$ Soaking the sample for four days. Forcing 19.4 sq.cm and (3sq.in) plunger into the sample depth of $2.5 \mathrm{~mm}(0.1$ in.)

Soil classification: This is the arrangement of soils into a different group in order that the soils in a particular group would have similar behavior. The method of classification used in this study was performed in accordance with the AASHTO M-145 System. The AASHTO Classification system is useful for classifying soils for a highway.

\section{Results and Discussion}

\subsection{Identification of Engineering properties of Natural Gravel}

Three gravel sources were selected near Sawla Town. From each of these three quarry sites, three representative samples were extracted for laboratory testing. Based on field observation, all the materials from the three quarry sites, only Duza composed of more weathered rocks. However, the natural gravel materials were easily produced by labor and machine by crushing the weathered rock. To determine the quality of the materials, laboratory tests were carried out. The tests involved identifying the properties of the natural gravel, such as its physical and mechanical properties. Soil test results showed it satisfied the requirements of ERA standard specification as a sub-base construction material.

\subsection{Laboratory Test Results}

\subsubsection{Atterberg's Limit Test Results}

The Liquid Limit and Plastic Limits of soil indicated a certain change in the physical behavior of soil water contents.

Table 2: Atterberg's Limit test of natural gravel for Mela quarry site

\begin{tabular}{|l|l|c|c|c|c|}
\hline Quarry site & Representative sample & \multicolumn{3}{|c|}{ Soil parameter } & ERA specification (range) \\
\hline \multirow{4}{*}{ Mela } & & LL & PL & PI & 6---12 \\
\cline { 2 - 6 } & Sample -1 & 35.07 & 26.06 & 9.01 & $6---12$ \\
\cline { 2 - 6 } & Sample -2 & 35.04 & 26.02 & 9.02 & $6---12$ \\
\cline { 2 - 6 } & Sample -3 & 35.00 & 26.00 & 9.00 & $6---12$ \\
\cline { 2 - 6 } & Average & 35.04 & 26.03 & 9.01 & \\
\hline
\end{tabular}


Table 2 shows little different test results of the three (3) samples collected from Duza quarry site. The three representative samples difference composed of around 0.004 .

Table 3: Atterberg's Limit test of natural gravel for Suka quarry site

\begin{tabular}{|l|l|c|c|c|c|}
\hline Quarry site & Representative sample & \multicolumn{3}{|c|}{ Soil parameter } & ERA specification (range) \\
\hline \multirow{4}{*}{ Suka } & & LL & PL & PI & \\
\cline { 2 - 6 } & Sample 1 & 44.05 & 31.07 & 12.98 & $6-12$ \\
\cline { 2 - 6 } & Sample 2 & 45.004 & 32.002 & 13.00 & $6-12$ \\
\cline { 2 - 6 } & Sample 3 & 44.08 & 31.07 & 13.03 & $6-12$ \\
\cline { 2 - 6 } & Average & 44.38 & 31.38 & 13.00 & $6-12$ \\
\hline
\end{tabular}

Table 4 shows the different test results of the three samples by comparing the soil parameters under the Atterberg's Limit tests. Sample 2 differed from the two samples, LL by 0.95 and 0.92 , PL by 0.93 and 0.94 , PI by 0.02 and 0.03 . The results of the three samples represented a little variation. However, the test results of PI indicated that the observed average value of $13 \%$, which was above the upper limit of $12 \%$ based on ERA standard specification.

Table 4: Atterberg's Limit test of natural gravel for Duza quarry site

\begin{tabular}{|l|l|c|c|c|c|c|}
\hline Quarry site & Representative sample & \multicolumn{2}{|c|}{ Soil parameter } & \multicolumn{2}{c|}{ ERA specification } \\
\hline \multirow{4}{*}{ Duza } & & LL & PL & PI & Lower & Upper \\
\cline { 2 - 7 } & Sample 1 & 46.500 & 23.00 & 23.50 & 6 & 12 \\
\cline { 2 - 7 } & Sample 2 & 47.000 & 23.00 & 24.00 & 6 & 12 \\
\cline { 2 - 7 } & Sample 3 & 47.017 & 22.24 & 22.78 & 6 & 12 \\
\cline { 2 - 7 } & Average & 47.000 & 23.08 & 23.90 & 6 & 12 \\
\hline
\end{tabular}

\subsubsection{Sieve Analyses}

To determine the gradation of natural aggregates, sieve analyses performed on samples collected from the three quarry sites. The result of the test used to determine the particle size distribution with applicable specification requirement and to provide necessary data for control of the production of various aggregate mixtures containing aggregate for the purpose of pavement material. Figure 2 indicates the test result of natural gravel for the Mela quarry site. The values are almost above the Upper Limit of the ERA standard specification of different sieve sizes. But only the $2 \mathrm{~mm}$ sieve size is nearest to the margin line of the upper limit.

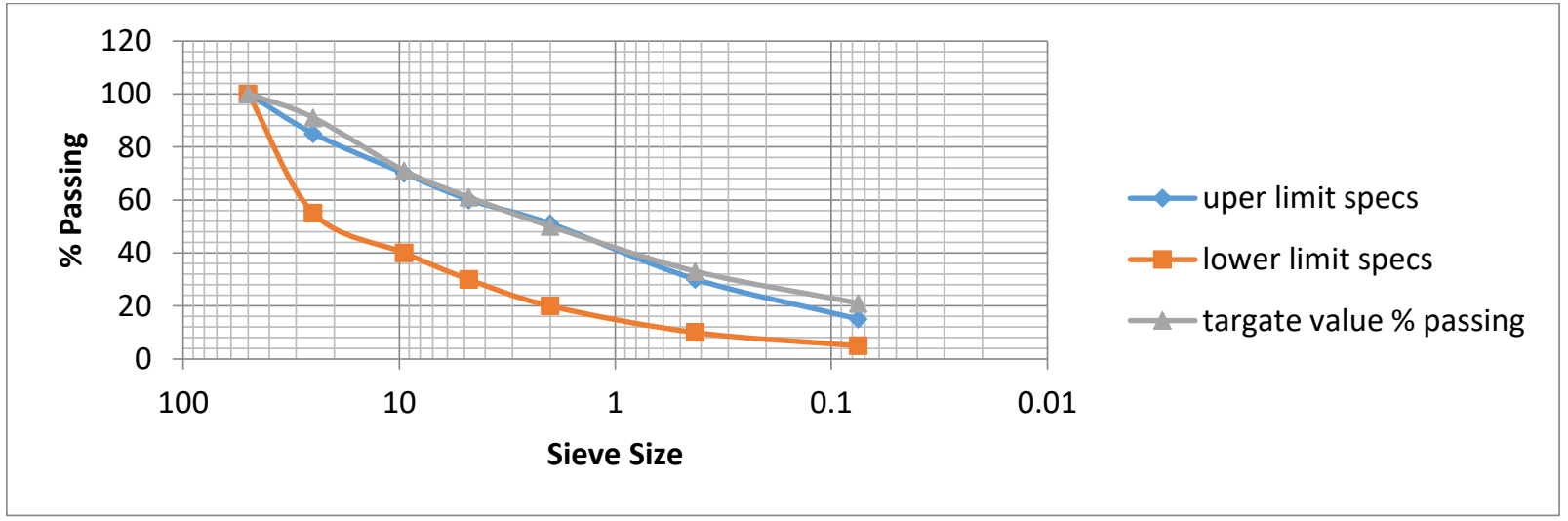

Figure 2: Result of Sieve analyses of natural gravel for Mela quarry sample 1 
Figure 3 shows the values which are above the upper Limit ERA standard specification of different sieve sizes. But only the $2 \mathrm{~mm}$ sieve size is the nearest to the margin line of the upper limit.

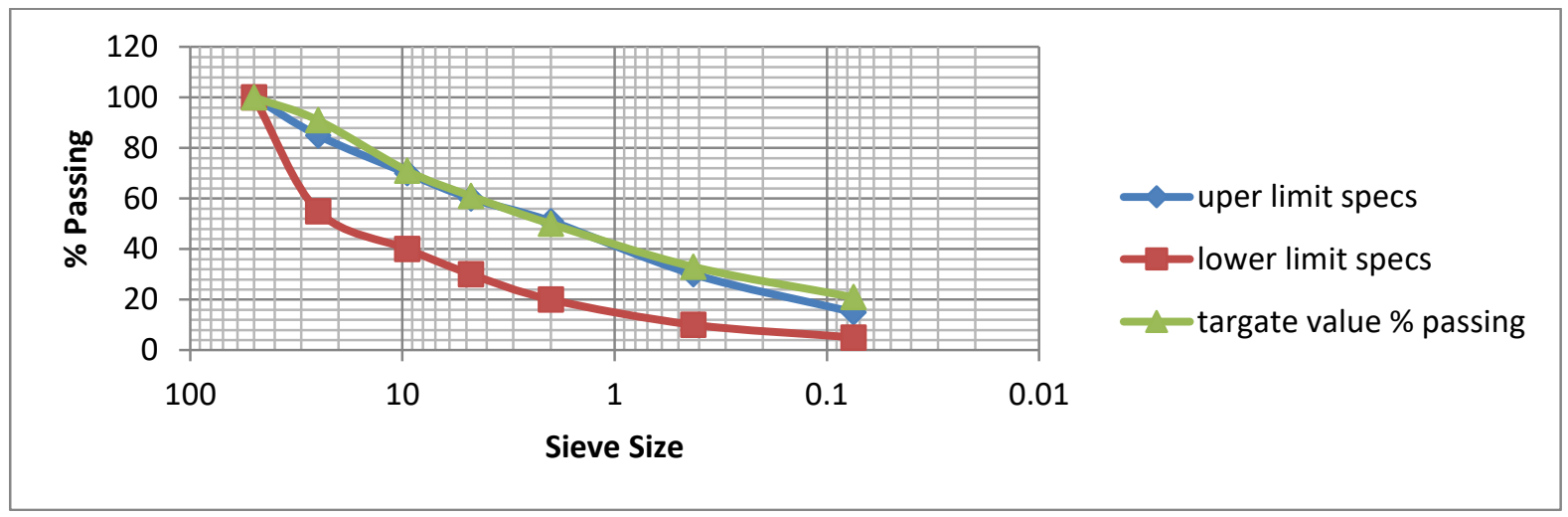

Figure 3: Result of Sieve analyses of natural gravel from Mela quarry for sample 2

Figure 4 shows the test result of natural gravel from Mela quarry Sample3 was above the ERA standard specification of different sieve sizes. These indicated the materials had finer particles.

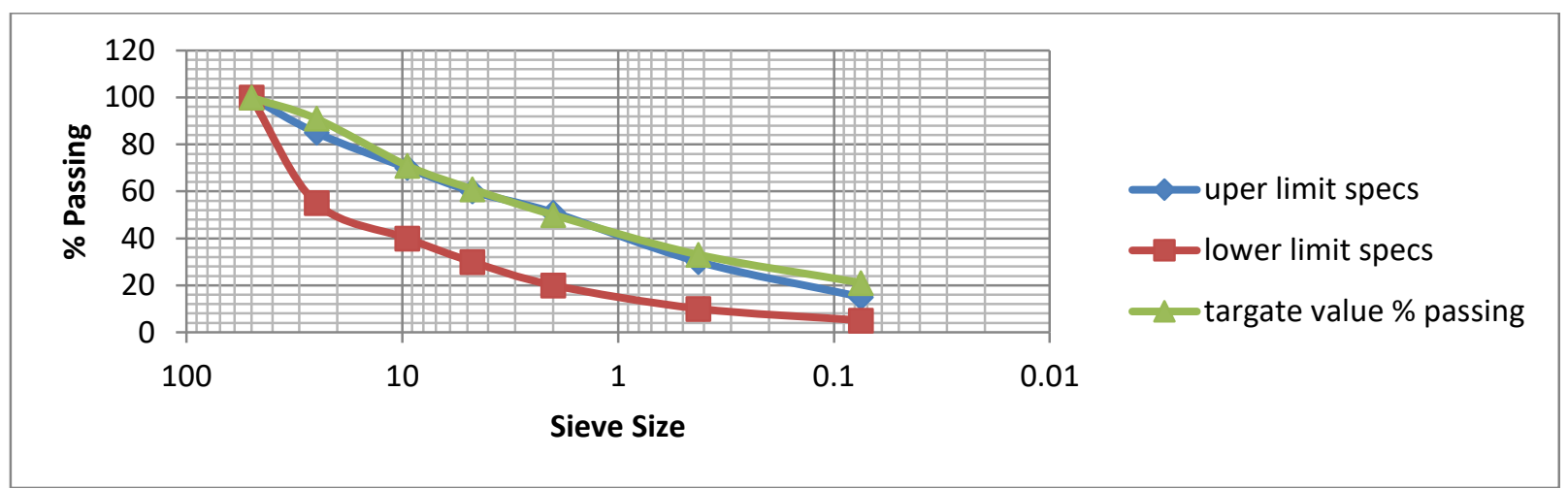

Figure 4: Results of Sieve analyses of natural gravel from Mela quarry for sample 3

Comparing the observed values of percent passing with the ERA standard specification, the later comprised values, not within the upper and lower limits at different standard sizes for use as subbase materials.

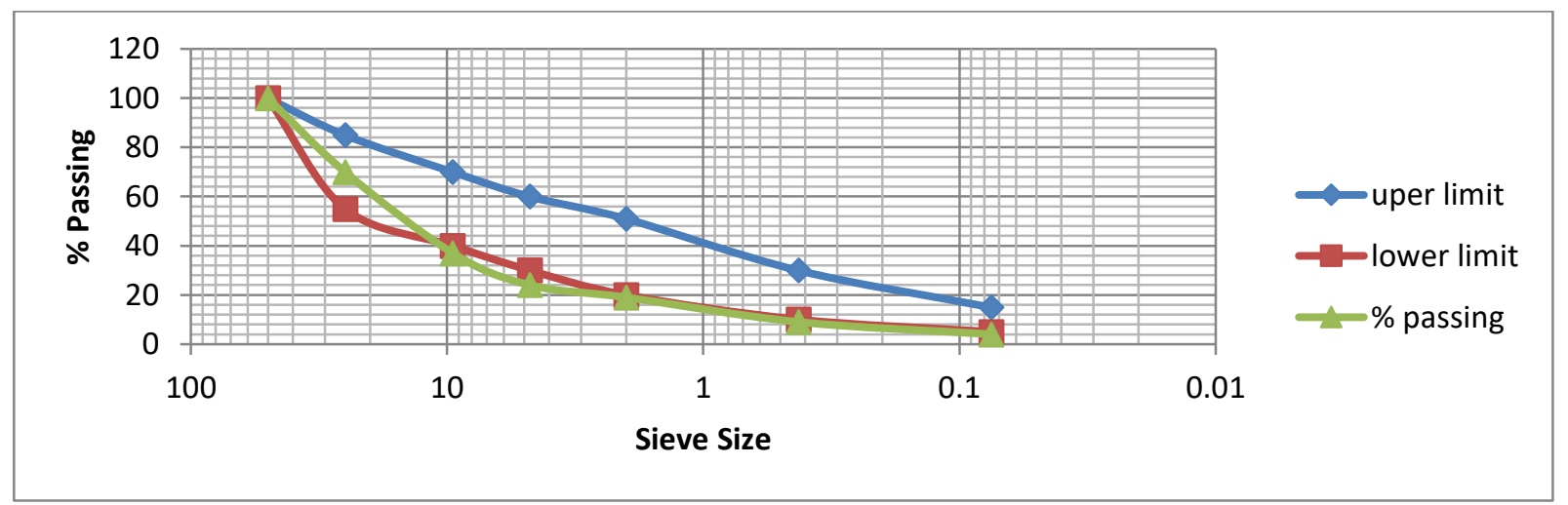

Figure 5: Result of Sieve analyses of natural gravel from Suka quarry sample 1 
Figure 6 below indicated the test result of natural gravel from the Suka quarry site for sample2. In comparing with ERA standard specification, the first and the second large sieve sizes are within the ERA standard specification, but sieve size $9.5(\mathrm{~mm})-0.075(\mathrm{~mm})$ is below the Lower limit of the specification. These indicated the materials were coarser and less fine or binder particles.

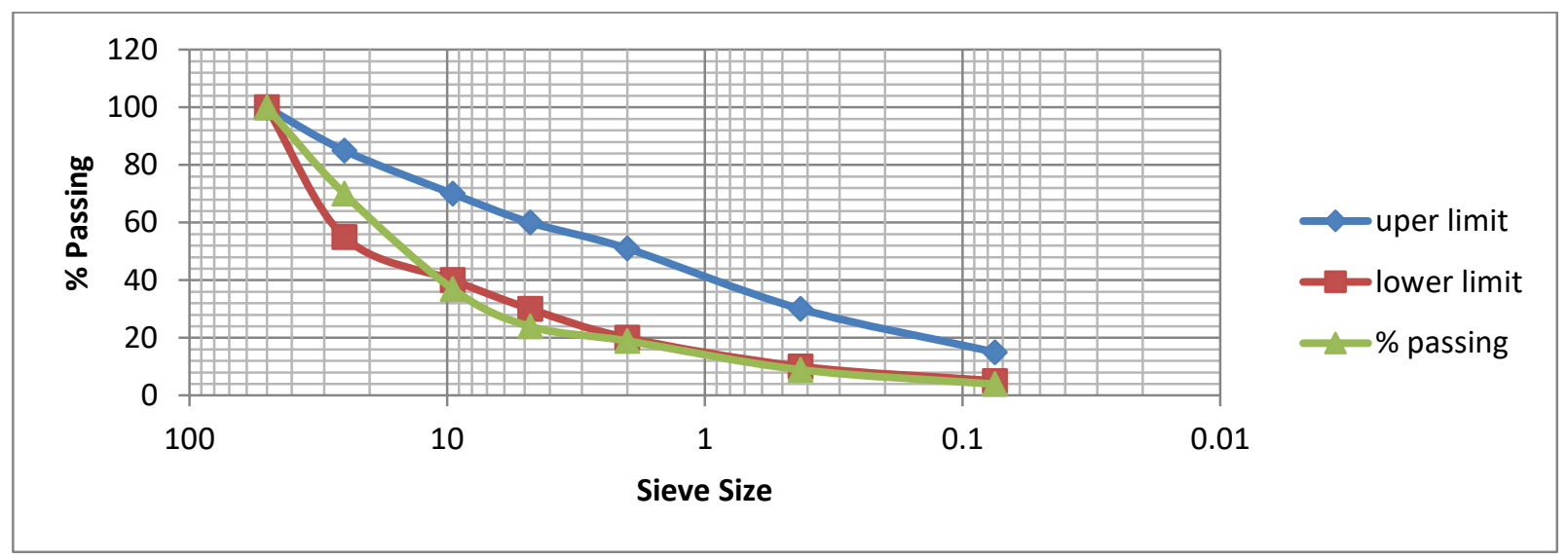

Figure 6: Result of Sieve analyses of natural gravel from Suka quarry site for sample 2

Figure 7 shows the test result of natural gravel from the Suka quarry site for sample 3. The sample observation with sample 2 when it was compared with the ERA standard specification. The first and the second large sieve sizes are within the ERA standard specification while the other sieve sizes are below the Lower limit of the standard specification. These pointed out; the materials are coarser and less fine or binders.

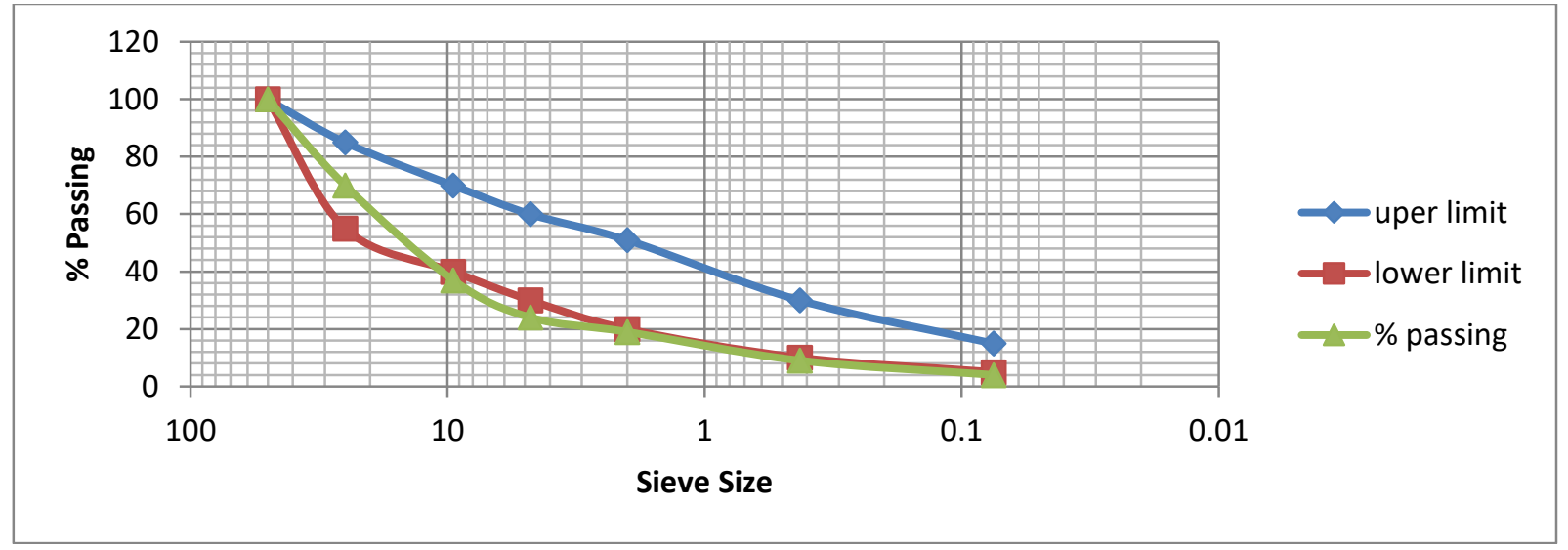

Figure 7: Result of Sieve analyses of natural gravel from Suka quarry site for sample 3

Figure 8 below indicated the above upper Limit of ERA standard specification. These showed, the materials composed of finer or less courser. 


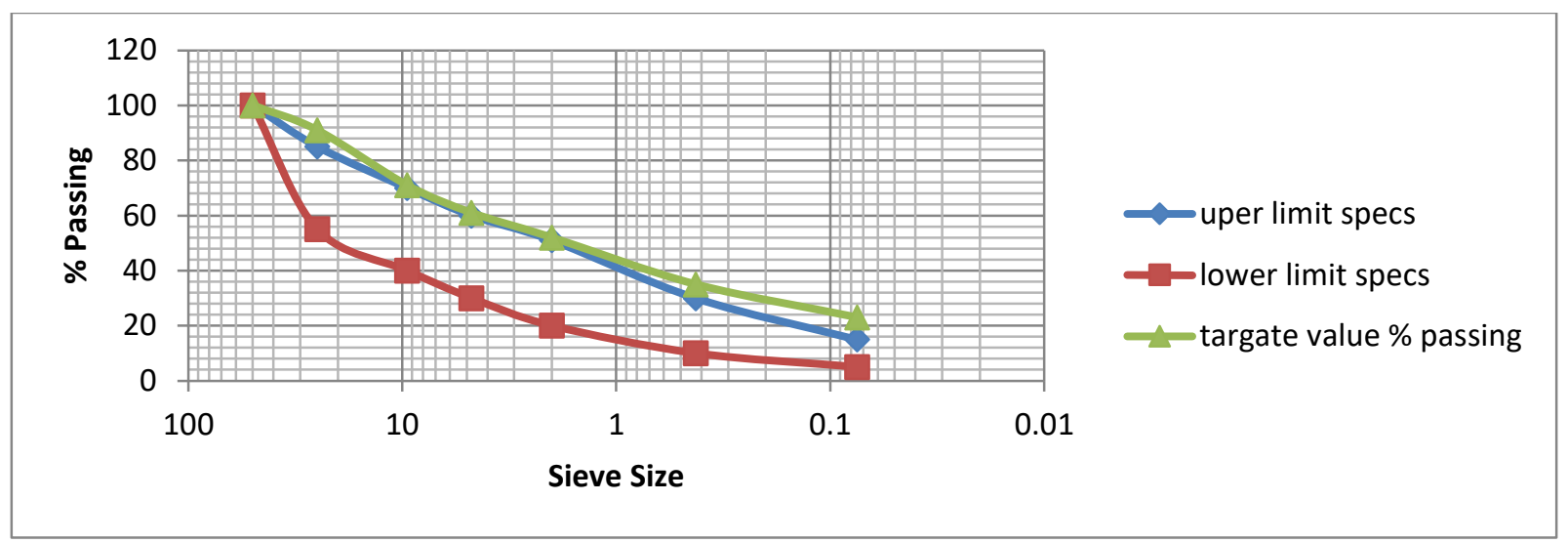

Figure 8: Result of Sieve analyses of natural gravel from Duza quarry site for sample 1

Figure 9 shows the result of Sieve analyses of natural gravel from Duza quarry site for sample 2 related the same observation with sample 1 . This means the materials are finer and less courser when comparing with the ERA standard specification of the lower and upper limit.

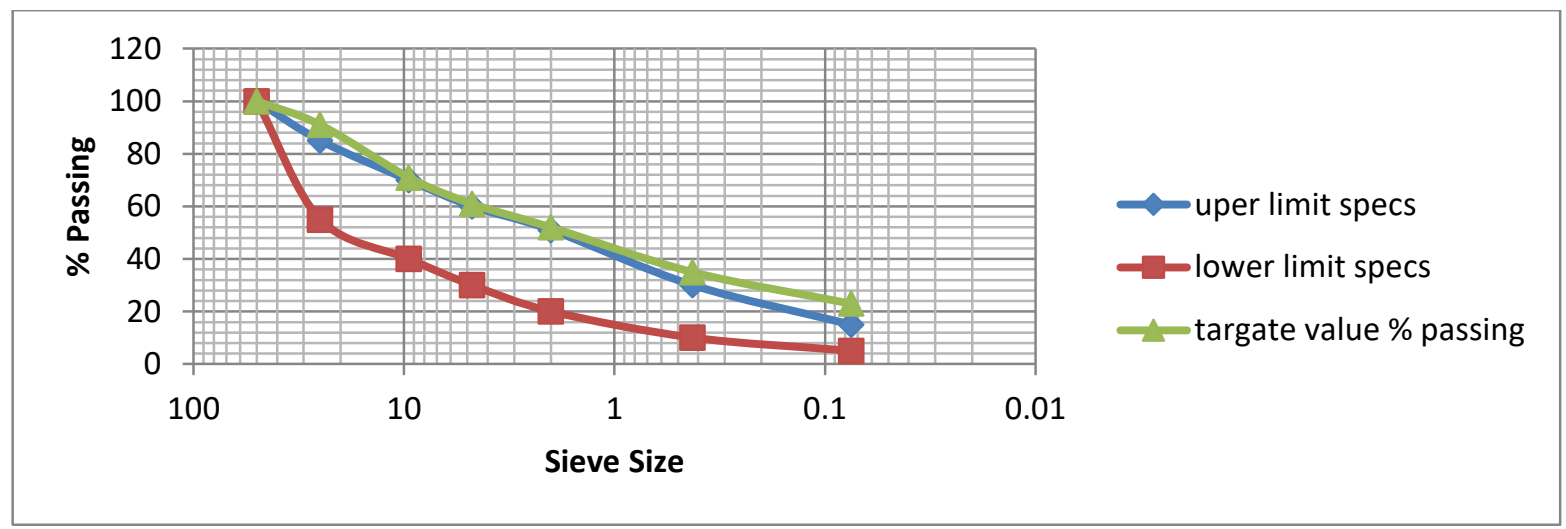

Figure 9: Result of Sieve analyses of natural gravel from Duza quarry site sample 2

All sieve sizes were above the Upper Limit of ERA standard specification. This means the material had a fine or fewer courser particle. According to Laboratory data, it indicated, the material out of the Upper Limit and Lower Limit of ERA standard specification for sub-base materials.

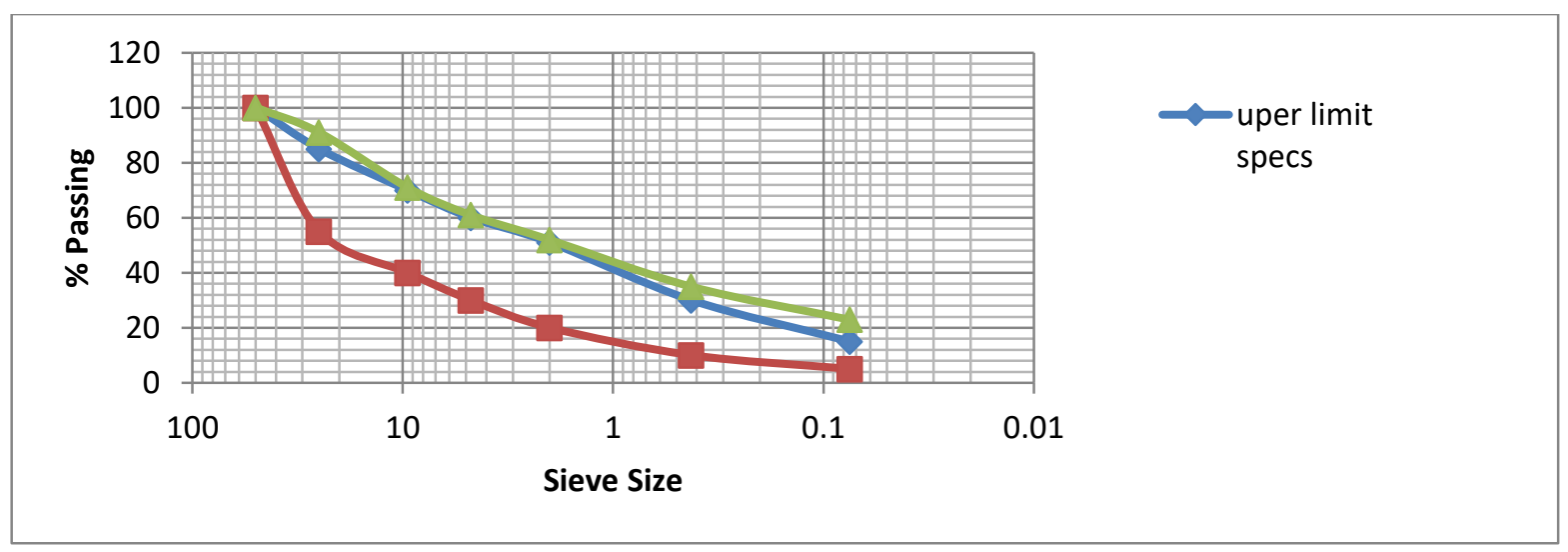

Figure 10: Result of Sieve analyses of natural gravel from Mela quarry sites for Sample 3 


\subsubsection{Los Angeles Abrasion Test}

Test method ASTM D: C 131 - 03: -The LAA value which was expressed as the percentage of fine passing the $1.18 \mathrm{~mm}$, BS (1.7mm ASTM) sieve an estimate of the abrasion resistance of the aggregate. The test result is tabulated in Table 5.

Table 5: Los Angeles Abrasion test result of natural gravel for different quarry site

\begin{tabular}{|l|l|l|c|r|}
\hline No & Parameters & Quarry site & Site average & ERA standard specification \\
\hline 1 & LAA & Suka & 35.26 & $\leq 51$, for 500 revolutions \\
\hline 2 & LAA & Mela & 52.09 & $\leq 51$, for 500 revolutions \\
\hline 3 & LAA & Duza & 78.34 & $\leq 51$, for 500 revolutions \\
\hline
\end{tabular}

Table 5 shows the Los Angeles Abrasion test result of natural gravel for the different quarry site of the study area. Based on the Laboratory test results Suka site consisted of high Abrasion resistance. Mela site revealed Low Abrasion resistance while Duza site was very low Abrasion resistance.

\subsubsection{Moisture-Density Relationship}

The modified compaction test method used to determine the relationship between the moisture content and density of soil when compacted in a given mold of a given size using $4.5 \mathrm{~kg}$ rammer and dropped from a height of $457 \mathrm{~mm}$. The values of different tests from quarry sites were tabulated below.

Table 6: Result of Compaction test of natural gravel for Suka, Mela and Duza quarry sites

\begin{tabular}{|l|c|c|}
\hline \multirow{2}{*}{ Quarry } & \multicolumn{2}{|c|}{ Parameters } \\
\cline { 2 - 3 } & MDD g/cc & OMC \% \\
\hline Mela & 2.1 & 9 \\
\hline Suka & 2.2 & 13 \\
\hline Duza & 2.6 & 17 \\
\hline
\end{tabular}

Table 6 shows the result of Compaction tests of natural gravel for Mela, Suka, and Duza quarry sites. Based on the laboratory test results, the two sites provided a good value. However, gravel from Mela revealed better in terms of optimum moisture content (OMC) than Suka quarry site, whereas Duza quarry site was not good.

\subsubsection{California Bearing Ratio (CBR) Test Results}

The test results obtained from the three different quarry sites are shown in Tables 6 and Table 7 . Based on test results, the values of the Mela quarry site indicated that the materials under the specified conditions could not be used for sub-base. 

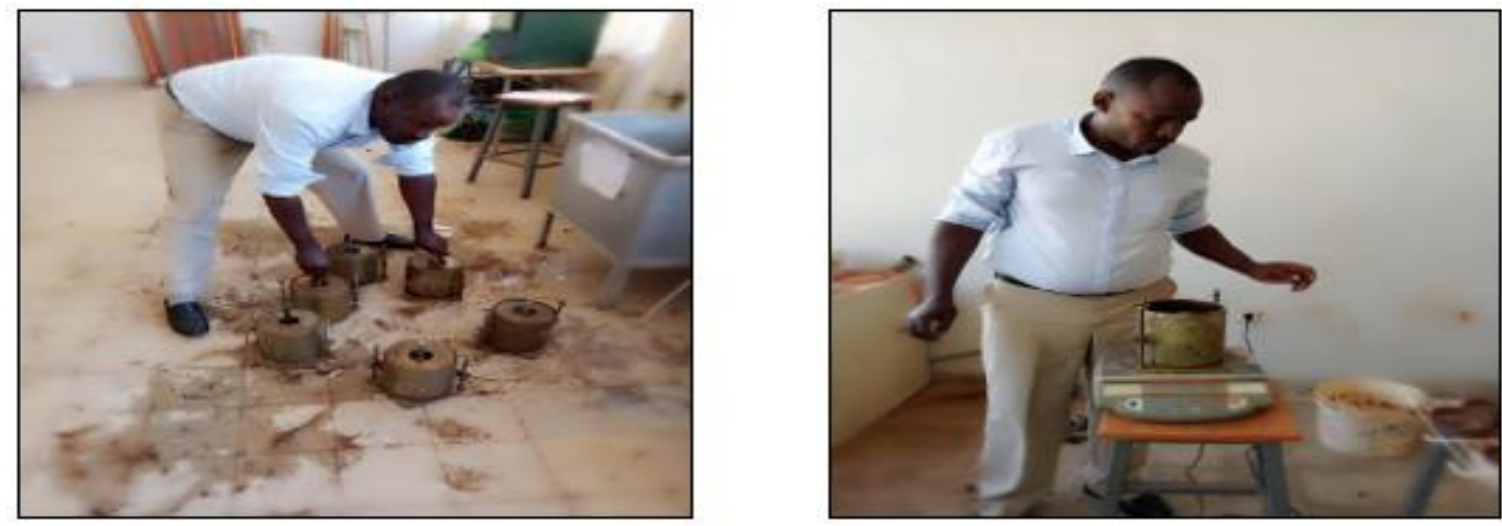

Figure 11: CBR testing in the laboratory

Table 7: California Bearing Ratio (CBR) test results of natural gravel for Mela quarry site

\begin{tabular}{|c|c|c|c|c|c|c|c|c|c|c|}
\hline$\stackrel{\overrightarrow{3}}{3}$ & $\begin{array}{l}\text { Representative } \\
\text { sample }\end{array}$ & $\begin{array}{l}\text { Para } \\
\text { meters }\end{array}$ & $\vec{F}$ & 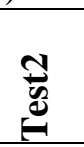 & $\stackrel{\mathscr{Z}}{\mathscr{E}}$ & $\underset{\tilde{E}}{\stackrel{+}{*}}$ & 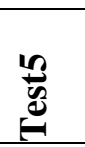 & $\begin{array}{l}\text { Trial } \\
\text { (Ave.) }\end{array}$ & $\begin{array}{l}\text { Site } \\
\text { (Ave.) }\end{array}$ & Specification \\
\hline \multirow{3}{*}{ Mela } & Sample 1 & CBR & 29 & 28.9 & 29 & 29 & 28.9 & 29 & \multirow{3}{*}{28.9} & $\geq 30$ \\
\hline & Sample 2 & $\mathrm{CBR}$ & 29 & 28.9 & 29 & 29 & 29.0 & 28.98 & & $\geq 30$ \\
\hline & Sample 3 & CBR & 29.0 & 28.9 & 29 & 29 & 29 & 28.98 & & $\geq 30$ \\
\hline
\end{tabular}

Table 8: California Bearing Ratio (CBR) test results of natural gravel for the Suka quarry site

\begin{tabular}{|c|c|c|c|c|c|c|c|c|c|c|}
\hline$\stackrel{\vec{E}}{\vec{E}}$ & $\begin{array}{l}\text { Representative } \\
\text { sample }\end{array}$ & Parameters & $\vec{\nabla}$ & 苞 & 䔅 & 莺 & 荡 & $\begin{array}{l}\text { Trial } \\
\text { (Ave.) }\end{array}$ & $\begin{array}{l}\text { Site } \\
\text { (Ave.) }\end{array}$ & $\begin{array}{l}\text { ERA } \\
\text { Specs }\end{array}$ \\
\hline \multirow{3}{*}{ Suka } & Sample1 & CBR & 34 & 34.98 & 34 & 34 & 34 & 33.98 & \multirow{3}{*}{33} & $>30$ \\
\hline & Sample 2 & CBR & 33.9 & 34 & 34.3 & 34 & 34 & 34.04 & & $\geq 30$ \\
\hline & Sample 3 & CBR & 34 & 34 & 34 & 34.9 & 34 & 34.98 & & $\geq 30$ \\
\hline
\end{tabular}

Table 9: California Bearing Ratio (CBR) test results of natural gravel for Duza quarry site

\begin{tabular}{|c|c|c|c|c|c|c|c|c|c|c|}
\hline$\stackrel{\vec{E}}{\vec{E}}$ & $\begin{array}{l}\text { Representative } \\
\text { sample }\end{array}$ & Parameters & $\overrightarrow{\tilde{V}^{\prime}}$ & 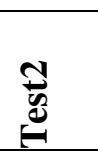 & 䔅 & $\begin{array}{l}\stackrel{D}{5} \\
\stackrel{5}{E} \\
E\end{array}$ & 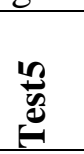 & $\begin{array}{l}\text { Trial } \\
\text { (Ave.) }\end{array}$ & $\begin{array}{l}\text { Site } \\
\text { (Ave.) }\end{array}$ & $\begin{array}{l}\text { ERA } \\
\text { Specs }\end{array}$ \\
\hline \multirow{3}{*}{ Duza } & Sample1 & CBR & 20.1 & 19.85 & 19.5 & 19.9 & 20.2 & 19.97 & \multirow{3}{*}{19.84} & $\geq 30$ \\
\hline & Sample 2 & CBR & 19.8 & 20.2 & 19.6 & 19.6 & 19.7 & 19.78 & & $\geq 30$ \\
\hline & Sample 3 & CBR & 19.8 & 19.7 & 19.6 & 20 & 19.7 & 19.77 & & $\geq 30$ \\
\hline
\end{tabular}

\subsection{Laboratory Test Result After Blending (After Mixed Proportion for Mechanical Stabilization in Laboratory) And Effects on Parameters}

The analysis in this section, the equations used, are indicated in the research methods section. The mixed ratio was obtained. Hereunder are the parameters and values obtained and used for the analysis:

$$
\begin{aligned}
& \mathrm{P}=9.5, \mathrm{~PB}=9, \mathrm{PA}=13, \mathrm{SA}=9.32, \mathrm{SB}=33.03 \\
& \text { Suka }(a) \quad=100 * 33.03(9.5-9) /[33.03(9.5-9)-9.32(9.5-13) \\
& =(33.6 \%) \\
& \text { Mela }(b)=100-a=(66.4 \%)
\end{aligned}
$$




\subsubsection{Atterberg's Limit}

Table 10: Atterberg's limit test result for the mix proportion

\begin{tabular}{|l|l|c|c|c|c|c|}
\hline $\begin{array}{l}\text { Quarry } \\
\text { Site }\end{array}$ & \multicolumn{2}{|l|}{ Representative } & \multicolumn{2}{|l|}{ Parameters } & \multicolumn{2}{c|}{ ERA Standard Specification } \\
\hline \multirow{3}{*}{ Mela+Suka } & $\begin{array}{l}\text { Mela (66.4\%) + Seuka } \\
(33.6 \%)\end{array}$ & LL & PL & PI & $\begin{array}{c}\text { Lower limit } \\
\text { (PI) }\end{array}$ & $\begin{array}{c}\text { Upper limit } \\
\text { (PI) }\end{array}$ \\
\cline { 2 - 7 } & Average & 35.52 & 26.00 & 9.52 & 6 & 12 \\
\hline
\end{tabular}

\subsubsection{Effects of Mixed proportion for Atterberg's Limit}

Table 11: Mix proportion

\begin{tabular}{|c|c|c|c|c|c|c|c|c|c|c|}
\hline \multirow[t]{3}{*}{$\begin{array}{l}\text { Quarry } \\
\text { site }\end{array}$} & \multicolumn{2}{|c|}{$\begin{array}{c}\text { Sample in percent } \\
(\%)\end{array}$} & \multicolumn{2}{|c|}{$\begin{array}{c}\text { Sample by dry mass } \\
(\mathbf{g m})\end{array}$} & \multicolumn{6}{|c|}{$\begin{array}{c}\text { Parameter value (initial \& } \\
\text { observed) }\end{array}$} \\
\hline & \multirow{2}{*}{$\begin{array}{c}\text { Normal } \\
(\%)\end{array}$} & \multirow{2}{*}{$\begin{array}{c}\text { Quarry } \\
(\%)\end{array}$} & \multirow{2}{*}{$\begin{array}{c}\text { Normal } \\
\text { (gm) }\end{array}$} & \multirow{2}{*}{$\begin{array}{c}\text { Quarry } \\
\text { (gm) }\end{array}$} & \multicolumn{2}{|c|}{ LL (\%) } & \multicolumn{2}{|c|}{ PL (\%) } & \multicolumn{2}{|c|}{ PI (\%) } \\
\hline & & & & & $\begin{array}{l}\text { 퓰 } \\
\text { 总 } \\
\text { Z }\end{array}$ & 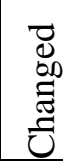 & $\begin{array}{l}\bar{\pi} \\
\stackrel{\pi}{\Xi} \\
\text { Z }\end{array}$ & 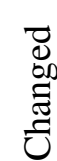 & $\begin{array}{l}\bar{T} \\
\text { 吾 } \\
\text { Z }\end{array}$ & 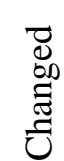 \\
\hline Suka & 100 & 33.6 & 500 & 270 & 44 & 35 & 31 & 26 & 13 & 9.5 \\
\hline Mela & 100 & 66.4 & 500 & 230 & & & & & & \\
\hline
\end{tabular}

\subsubsection{Results of Grain-size Analysis}

The results of grain size analysis are plotted in Table 12 and Figure 12 below.

Figure 12 shows the Grain size analysis test results after blending of samples from Mela and Suka quarry site on the standard sieve size passing percent within the standard specification. The values are within the lower and upper limits. This means that the materials taken from quarry sites with the above mix proportion satisfied the ERA standard specification. The materials fulfilled the ERA standard specification for use as sub-base materials road construction.

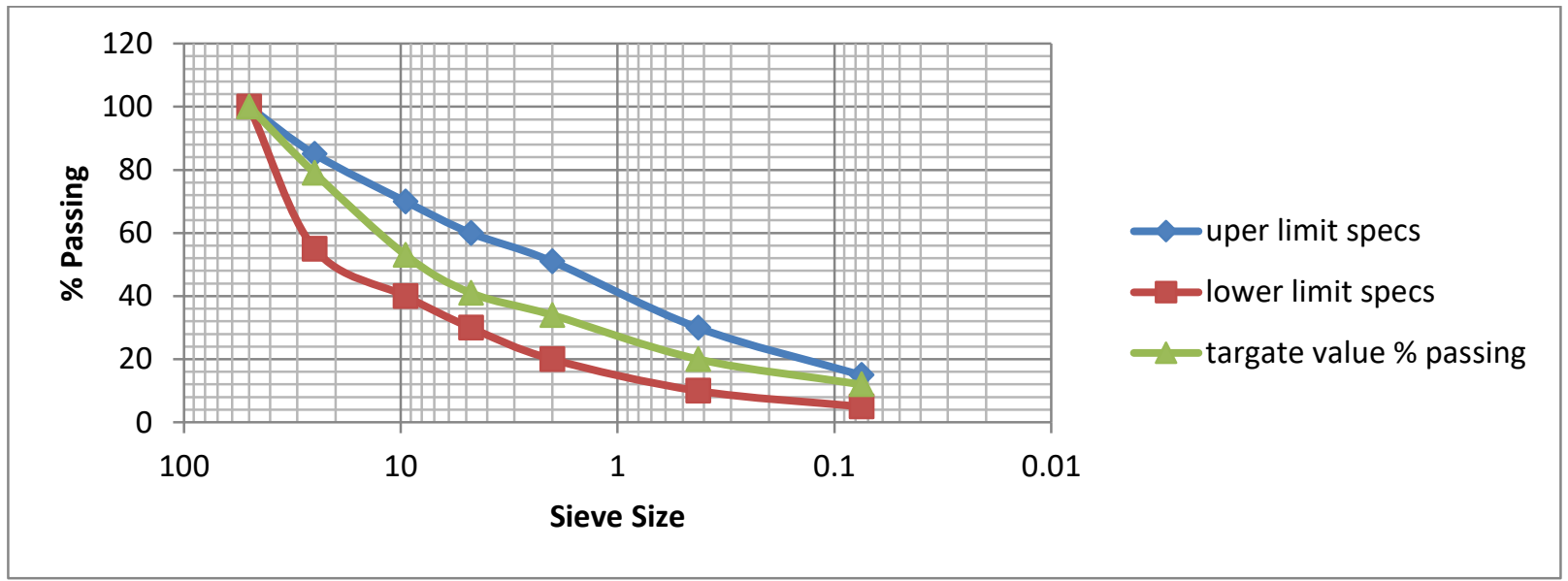

Figure 12: Grain size analysis test results after blending [Mela (66.4\%) + Seuka (33.6\%)]. 


\subsection{Effects of Mixed proportion for Gradation}

Table 12: Mixed proportion for Gradation

\begin{tabular}{|c|c|c|c|c|c|c|c|c|c|c|c|c|}
\hline \multirow{3}{*}{ 离 } & \multicolumn{2}{|c|}{$\begin{array}{l}\text { Sample } \\
(\%)\end{array}$} & \multicolumn{2}{|c|}{$\begin{array}{l}\text { Sample take } \\
\text { by dry mass }\end{array}$} & \multicolumn{6}{|c|}{ Parameter } & \multicolumn{2}{|c|}{$\begin{array}{c}\text { ERA } \\
\text { Specification }\end{array}$} \\
\hline & \multirow{2}{*}{ 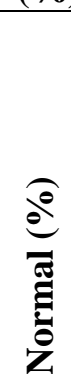 } & \multirow{2}{*}{ 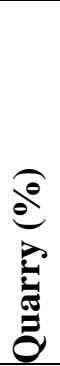 } & \multirow{2}{*}{ 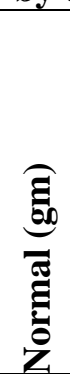 } & \multirow{2}{*}{ 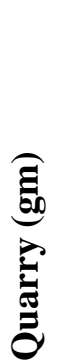 } & \multirow{2}{*}{ 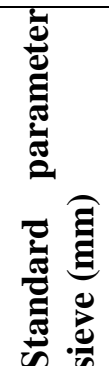 } & \multicolumn{2}{|c|}{$\begin{array}{c}\text { Natural } \\
\text { parameter of } \\
\text { each quarry on } \\
\text { each sieve }\end{array}$} & \multicolumn{2}{|c|}{$\begin{array}{c}\text { Change } \\
\text { parameter each } \\
\text { of quarry on } \\
\text { each sieve }\end{array}$} & \multirow{2}{*}{ 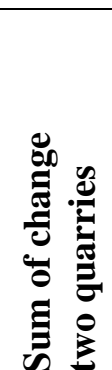 } & \multirow{2}{*}{ 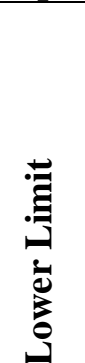 } & \multirow{2}{*}{ 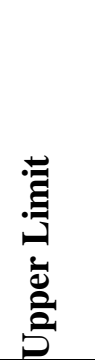 } \\
\hline & & & & & & $\sum_{\sum}^{\frac{\pi}{d}}$ & $\underset{\mathscr{Z}}{3}$ & $\sum_{\sum}^{\frac{\pi}{d}}$ & $\sum_{i}^{\frac{\pi}{d}}$ & & & \\
\hline \multirow{4}{*}{$\begin{array}{l}\frac{\pi}{3} \\
\tilde{n}\end{array}$} & \multirow{4}{*}{8} & \multirow{4}{*}{$\underset{m}{\dot{m}}$} & \multirow{4}{*}{8} & \multirow{4}{*}{ 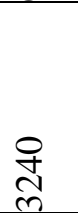 } & 50 & 100 & 100 & 66.4 & 33.6 & 100 & 100 & 100 \\
\hline & & & & & 25 & 70.3 & 90.66 & 41.70 & 37.82 & 79.6 & 55 & 85 \\
\hline & & & & & 9.5 & 37 & 71.1 & 32.7 & 19.94 & 52.64 & 40 & 70 \\
\hline & & & & & 4.75 & 24 & 61.11 & 28.11 & 13.07 & 41.12 & 30 & 60 \\
\hline \multirow{3}{*}{ 正 } & \multirow{3}{*}{8} & \multirow{3}{*}{$\underset{\emptyset}{\forall}$} & \multirow{3}{*}{8} & \multirow{3}{*}{$\stackrel{8}{2}$} & 2 & 19.42 & 50.01 & 23.05 & 10.409 & 33.54 & 20 & 51 \\
\hline & & & & & 0.425 & 9.32 & 33.03 & 15.19 & 5.03 & 20.22 & 10 & 30 \\
\hline & & & & & 0.075 & 4.2 & 20.76 & 9.55 & 2.27 & 11.82 & 5 & 15 \\
\hline
\end{tabular}

Table 12 shows the Grain size analysis test results after blending. This means the standard sieve size passing percent was within the standard specification. It also implied that materials fulfilled the ERA standard specification for use as sub-base materials in road construction around Sawla Town.

\subsubsection{Los Angeles Abrasion Test Results After Blending}

Table 13: Loss Angeles Abrasion test result

\begin{tabular}{|c|c|c|c|c|c|c|c|c|c|c|}
\hline No & Quarry & $\begin{array}{c}\text { Representative } \\
\text { Sample }\end{array}$ & 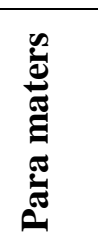 & 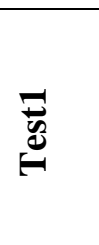 & 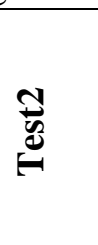 & 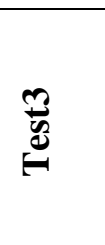 & 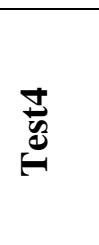 & 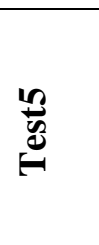 & 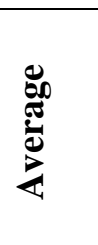 & $\begin{array}{c}\text { ERA } \\
\text { Specification }\end{array}$ \\
\hline 1 & $\begin{array}{l}\text { Mela+ } \\
\text { Suka }\end{array}$ & $\begin{array}{l}\text { Mela }(66.4 \%)+ \\
\text { Suka }(33.6 \%)\end{array}$ & LAA & 34.01 & 34.00 & 34.00 & 34.01 & 34.01 & 34.01 & $\leq 51$ \\
\hline
\end{tabular}

Table 13 shows the Loss Angeles Abrasion test result after blending. The average value is bigger than the value set forth under the ERA standard specification for the abrasion resistance impact value. This means the materials satisfied the ERA standard specification after mixed with the proportion of Mela (66.4\%) and Suka (33.6\%) for use as sub-base materials road construction. 


\subsubsection{Moisture-Density Relation (Compaction) Test Result After Blending}

The test result is given in Table 14 below.

Table 14: Laboratory test results in moisture-density relation after blending.

\begin{tabular}{|l|c|c|c|}
\hline Quarry Site & Representative Sample & \multicolumn{2}{|c|}{ Parameters } \\
\cline { 3 - 4 } & & MDD & OMC \\
\hline Mela +Suka & Mela (66.4\%) + Suka (33.6\%) & $2.105 \mathrm{~g} / \mathrm{cc}$ & $12.00 \%$ \\
\hline
\end{tabular}

\subsection{Effects of Soil Samples After Blending Compaction}

Table 15: Samples after blending

\begin{tabular}{|c|c|c|c|c|c|c|c|c|}
\hline \multirow{3}{*}{ 莺 } & \multicolumn{2}{|c|}{$\begin{array}{c}\text { Sample in percent } \\
(\%)\end{array}$} & \multicolumn{2}{|c|}{$\begin{array}{c}\text { Sample by dry mass } \\
(\mathrm{gm})\end{array}$} & \multicolumn{4}{|c|}{ Parameter value (natural \& observed) } \\
\hline & Normal & Quarry & Normal & Quarry & MDD & OMC & MDD & OMC \\
\hline & $(\%)$ & $(\%)$ & (gm) & $(\mathrm{gm})$ & Natural & Natural & Changed & Changed \\
\hline Suka & 100 & 33.6 & 6000 & 3240 & \multirow{2}{*}{$2.2 \mathrm{~g} / \mathrm{cc}$} & \multirow{2}{*}{13} & \multirow{2}{*}{2.105} & \multirow[t]{2}{*}{12} \\
\hline Mela & 100 & 66.4 & 6000 & 2760 & & & & \\
\hline
\end{tabular}

Table 15 shows laboratory test results before and after blending samples from quarry sites. The values of MDD and OMC have improved the condition of the mixed sample. This result indicated that the materials when mixed with Mela (66.4\%) and Suka (33.6\%), it satisfied the ERA standard specification.

\subsubsection{California Bearing Ratio (CBR) Test Result After Blending}

The test result is given in Table 16 below.

Table 16: Laboratory test result (CBR) Mela (66.4\%) +Suka (33.6\%)

\begin{tabular}{|l|l|c|c|}
\hline Quarry Site & Representative sample & Parameters & Specification \\
\hline Mela + Suka & Mela $(66.4 \%)+\operatorname{Suka}(33.6 \%)$ & CBR & \\
\cline { 3 - 4 } & & 40.00 & $\geq 30$ \\
\hline
\end{tabular}

Table 17: Effects of mix proportion in CBR.

\begin{tabular}{|c|c|c|c|c|c|c|}
\hline \multirow{3}{*}{ 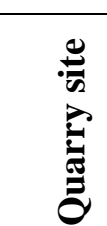 } & \multicolumn{2}{|c|}{$\begin{array}{c}\text { Sample in percent } \\
(\%)\end{array}$} & \multicolumn{2}{|c|}{ Sample by dry mass (gm) } & \multirow{2}{*}{\multicolumn{2}{|c|}{$\begin{array}{c}\begin{array}{c}\text { Parameter value (natural \& } \\
\text { observed) }\end{array} \\
\text { CBR } \\
\end{array}$}} \\
\hline & \multirow{2}{*}{$\begin{array}{c}\text { Normal } \\
(\%)\end{array}$} & \multirow{2}{*}{$\begin{array}{c}\text { Quarry } \\
(\%)\end{array}$} & \multirow{2}{*}{$\begin{array}{c}\text { Normal } \\
(\mathbf{G m})\end{array}$} & \multirow{2}{*}{$\begin{array}{c}\text { Quarry } \\
\text { (gm) }\end{array}$} & & \\
\hline & & & & & Natural & Observed \\
\hline Suka & 100 & 33.6 & 6000 & 3240 & 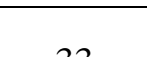 & \\
\hline Mela & 100 & 66.4 & 6000 & 2760 & 33 & 40 \\
\hline
\end{tabular}

Table 17 shows the laboratory test results before and after blending. The value of CBR has been improved the condition of materials. This means the material satisfied ERA standard specification. Hence it is possible to use the aggregates as sub-base materials for road construction. 


\subsection{Discussion}

The following comparisons and discussions are based on all data analyses conducted in the laboratory tests. The samples gathered from the study area of Sawla Town that can be used for Road Projects are presented hereunder:

\subsubsection{Atterberg's Limit}

From the laboratory test results, the average Liquid Limit, Plasticity limit and Plasticity Index of the different quarry sites and its representative samples, as well as sample, is summarized before blending and after blending.

Table 18: Summary of Atterberg's limit tests

\begin{tabular}{|l|l|l|l|l|}
\hline Quarry sites & LL & PL & PI & ERA Specification \\
\hline Mela & 35 & 26 & 9 & $6-12$ \\
\hline Suka & 44 & 31 & 13 & $6-12$ \\
\hline Mela (66.4\%) + Suka (33.4\%) & 35 & 26 & 9.5 & $6-12$ \\
\hline
\end{tabular}

Laboratory test results for the different samples revealed that Suka and Mela quarry sites composed of sizes higher or beyond the upper limit based from ERA standard specification in PI values. However, in order to improve and meet the equivalents percent composition of $66.4 \%$ and $33.6 \%$ for Duza and Suka quarry sites used, respectively.

\subsubsection{Grain Size Analysis}

Comparing the laboratory test results for gradation with that of the specification for sub-base, the results indicated that for all the three quarry sites did not completely satisfy with the limits materials. The Duza and Mela quarry sites had the same gradation properties or have fewer courser particles. The Suka quarry site composed of less fine particles and did not satisfy the specification. In considering Mela and Suka sites, the blending of these specimens with the established mix proportion revealed a value that was within the limit of the specification. The Laboratory test results of different quarry sites and its representative samples and result after blending is summarized below.

Table 19: Sieve analyses Laboratory results of different quarry sites and its representative sample and result after blending.

\begin{tabular}{|l|c|c|c|c|c|}
\hline \multirow{2}{*}{ Sieve size(mm) } & \multicolumn{4}{|c|}{ Quarry } & After blending \\
\cline { 2 - 6 } & Mela & Suka & Duza & Specification & Mela(66.4\%) + Suka(33.6\%) \\
\hline 50 & 100.00 & 100 & 100 & 100 & 100 \\
\hline 25 & 90.66 & 70.30 & 91.00 & $55-85$ & 79 \\
\hline 9.5 & 71.07 & 37.00 & 71.00 & $40-70$ & 52.64 \\
\hline 4.75 & 61.10 & 24.00 & 61.00 & $30-60$ & 41.12 \\
\hline 2 & 50.01 & 19.42 & 52.00 & $20-51$ & 33.54 \\
\hline 0.425 & 33.03 & 9.32 & 35.33 & $10-30$ & 20.21 \\
\hline 0.075 & 20.76 & 4.20 & 23.00 & $5-15$ & 11.82 \\
\hline
\end{tabular}




\subsubsection{Compaction Test}

Good compaction produced tightly bound gravel with optimum particle interlock. Minimum Permeability and porosity have significantly increased the soil strength, while a high degree of moist compaction resulted in a road with a lower roughness than similar materials which are poorly compacted in a dry condition. The roughness deterioration can be much slower, and gravel loss and dust emission can be significantly reduced. The average MDD for the natural sub-base material from different quarry sites indicated little differently. The OMC of Suka quarry site was higher than the Mela quarry site. However, after blending, the mix proportion of two quarry sites Suka(33.6\%) + Mela(66.4\%), the MDD \& OMC of the Suka quarry had changed. The laboratory test results are shown below.

Table 20: OMC \& MDD Laboratory data result from different quarry sites and its representative sample and results after blending.

\begin{tabular}{|l|c|c|c|}
\hline \multirow{2}{*}{ Parameters } & \multicolumn{3}{|c|}{ Quarry sites/samples } \\
\cline { 2 - 4 } & Suka & Mela & Suka(33.6\%) + Mela(66.4\%) \\
\hline MDD & $2.2 \mathrm{~g} / \mathrm{cc}$ & $2.1 \mathrm{~g} / \mathrm{cc}$ & $2.105 \mathrm{~g} / \mathrm{cc}$ \\
\hline OMC & $13 \%$ & $10 \%$ & $12 \%$ \\
\hline
\end{tabular}

\subsubsection{California Bearing Ratio (CBR) Test}

The average CBR obtained from different quarry sites when compacted at its optimum moisture content, and maximum dry density indicated below standard. The Suka quarry sample composed $34 \%$ in CBR value while Mela quarry sample revealed below the standard specification $29 \%$. However, after blending the two samples from the quarry sites considered in the mix proportion, the CBR value increased due to improving gradation of the materials. While the fine material fills the voids between coarser particles. The laboratory data are tabulated in Table 21.

Table 21: Summary of CBR Laboratory data result of different quarry sites and its representative sample and the result after blending.

\begin{tabular}{|l|c|c|c|}
\hline \multirow{2}{*}{ Parameters } & \multicolumn{2}{|c|}{ Quarry before blending } & After blending \\
\cline { 2 - 4 } & Suka & Mela & Suka(33.6\%) + Mela(66.4\%) \\
\hline CBR & 34 & 28.9 & 40 \\
\hline
\end{tabular}

\subsubsection{Los Angeles Abrasion Test}

The results are shown in Table 22, the average percentage of the sub-base course materials for the different results of the Los Angeles resistance. The test was also conducted on the natural sub-base materials, is used to establish the baseline data. The average percentage of sub-base for the Suka quarry site was $35 \%$ and represented good resistance because it is within the limit of the ERA standard specification. The specification requires the value to be not more than $51 \%$. Hence the compacted abrasion values are good and are within the acceptable limit based on the project specification and ERA standard Manual [28]. The Mela quarry site indicated low Los Angeles resistance because it is more than 51\%. The samples collected from Duza showed very low values of abrasion resistance. 
Table 22: Summary of laboratory test results

\begin{tabular}{|c|c|c|c|c|c|c|c|c|c|c|c|}
\hline \multirow{5}{*}{ 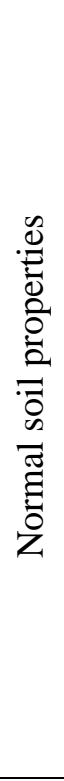 } & \multirow{2}{*}{ 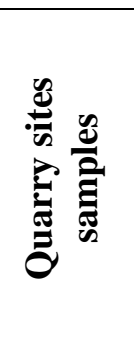 } & \multicolumn{2}{|c|}{ PI } & \multicolumn{2}{|c|}{ Gradation } & \multicolumn{2}{|l|}{ LAA } & \multicolumn{2}{|c|}{$\begin{array}{c}\text { Moisture } \\
\text { density } \\
\text { (Compaction) } \\
\end{array}$} & \multicolumn{2}{|c|}{$\begin{array}{c}\text { CBR } \\
\text { (sub-base) }\end{array}$} \\
\hline & & $\begin{array}{l}: \\
0 \\
0 \\
0 \\
0 \\
0\end{array}$ & $\frac{\tilde{U}}{\infty}$ & 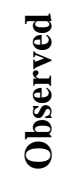 & ڤ્ठ & 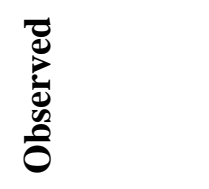 & $\underbrace{n}_{\mathscr{L}}$ & $\sum_{0}^{U}$ & $\hat{\mathrm{\theta}}$ & 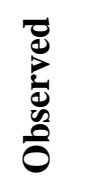 & $\frac{\mathscr{E}}{\mathscr{n}}$ \\
\hline & $\begin{array}{l}\text { Suka } \\
\text { sample }\end{array}$ & 13 & $6-12$ & \multicolumn{2}{|c|}{$\begin{array}{l}\text { Grain size } \\
\text { below the Limit } \\
\text { from } 9.5 \mathrm{~mm}- \\
0.075 \mathrm{~mm} .\end{array}$} & $\begin{array}{l}35.26 \text { (High } \\
\text { resistance) }\end{array}$ & $\leq 51$ & 14.50 & $2.2 \mathrm{~g} / \mathrm{cc}$ & 34.01 & $\geq 30$ \\
\hline & $\begin{array}{l}\text { Mela } \\
\text { sample }\end{array}$ & 9 & $6-12$ & \multicolumn{2}{|c|}{$\begin{array}{l}\text { Grain size } \\
\text { above the Upper } \\
\text { Limit. }\end{array}$} & $\begin{array}{l}52.09 \text { (Low } \\
\text { resistance) }\end{array}$ & $\leq 51$ & 10 & $2.1 \mathrm{~g} / \mathrm{cc}$ & 28.90 & $\geq 30$ \\
\hline & $\begin{array}{l}\text { Duza } \\
\text { sample }\end{array}$ & 23.90 & $6-12$ & \multicolumn{2}{|c|}{$\begin{array}{l}\text { Grain size } \\
\text { above the Upper } \\
\text { Limit }\end{array}$} & $\begin{array}{l}78.34 \text { (very } \\
\text { low } \\
\text { resistance) }\end{array}$ & $\leq 51$ & - & - & - & - \\
\hline
\end{tabular}

Table 23: Mix proportion laboratory test results

\begin{tabular}{|c|c|c|c|c|c|c|c|c|c|c|c|c|c|}
\hline \multirow{4}{*}{ 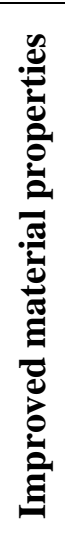 } & \multirow{3}{*}{ 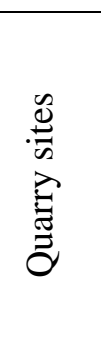 } & \multirow{2}{*}{\multicolumn{2}{|c|}{ PI }} & \multirow{2}{*}{\multicolumn{2}{|c|}{ Gradation }} & \multirow{2}{*}{\multicolumn{2}{|c|}{ LAA }} & \multicolumn{4}{|c|}{$\begin{array}{c}\text { Compaction (Dry } \\
\text { Density) }\end{array}$} & \multirow{2}{*}{\multicolumn{2}{|c|}{ CBR }} \\
\hline & & & & & & & & & & MI & & & \\
\hline & & 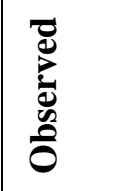 & 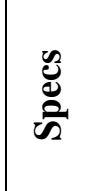 & 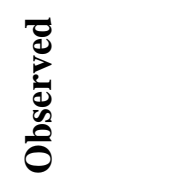 & $\begin{array}{l}\text { Uू } \\
\text { के }\end{array}$ & 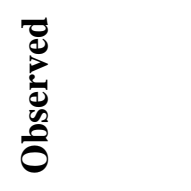 & $\begin{array}{l}\text { Uूँ } \\
\text { के }\end{array}$ & 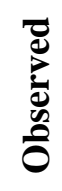 & $\begin{array}{l}\mathscr{U} \\
\text { के }\end{array}$ & $\begin{array}{l}\text { Do } \\
e_{0}^{0} \\
0 \\
0\end{array}$ & 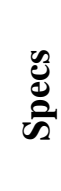 & 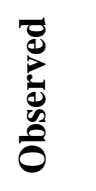 & $\frac{\mathscr{J}}{\text { की }}$ \\
\hline & $\begin{array}{l}\text { Mela } \\
+ \\
\text { Suka }\end{array}$ & 9.5 .02 & $6-12$ & $\begin{array}{l}\text { All sieve } \\
\text { sizes are } \\
\text { within } \\
\text { the limits }\end{array}$ & - & $\begin{array}{l}34.01 \\
\text { (High } \\
\text { resistance) }\end{array}$ & $\leq 51$ & 13 & & 2.105 & & 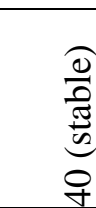 & $\geq 30$ \\
\hline
\end{tabular}

Note: Percent composition of samples for blending

Mela soil sample $=66.4 \%$ by weight

Suka soil sample $=33.6 \%$ by weight

\subsection{The Effect of Mechanical Stabilization on Cost}

\subsubsection{Material Production and Transportation Cost Estimation}

Mechanical stabilization accomplished by mixing of soils of two or more gradations to obtain material complying the required specifications. The soil blending conducted at the construction site of the central plant. The source of the blended materials is a Suka quarry site at the distant of $4 \mathrm{k} / \mathrm{m}$ from the town center and the Mela quarry site, which is $10 \mathrm{k} / \mathrm{m}$ away from the Sawla town. On the other hand, the alternative crushed aggregate located at $30 \mathrm{k} / \mathrm{m}$ near to the Maze park crusher site, and it costs 100 ETB in addition to transportation cost to purchase from MSEs. The area was already delineated for MSEs. This installation of the crusher machine not supported by the local government. 
Cost of crushed aggregate per $\mathrm{m}^{3}$

- Purchasing cost for crushed aggregate $=100 \mathrm{ETB} / \mathrm{m}^{3}$

- Transportation cost (including fuel cost) per $\mathrm{m}^{3}=100 \mathrm{ETB} / \mathrm{km} / \mathrm{m}^{3}$

Cost for mechanically stabilized material production per $\mathrm{m}^{3}$

- Transportation cost (including fuel cost) per $\mathrm{m}^{3}=100 \mathrm{ETB} / \mathrm{km} / \mathrm{m}^{3}$

- Additional construction cost per $\mathrm{m}^{3}=50 \mathrm{ETB} / 100 \mathrm{~L} \cdot \mathrm{m} / \mathrm{m}^{3}$

The Cost analysis included determining if the cost of the blending of materials from the quarry sites was economical when compared with crushed aggregates taken from the crushing plant. The following dimensions assumed: $1.0 \mathrm{~km}$ unpaved road selected within the study in Sawla road section at Kusti kebele, $7.2 \mathrm{~m}$ width, $0.4 \mathrm{~m}$ thick sub-base course, $0.3 \mathrm{~m}$ thick base course(surfacing).

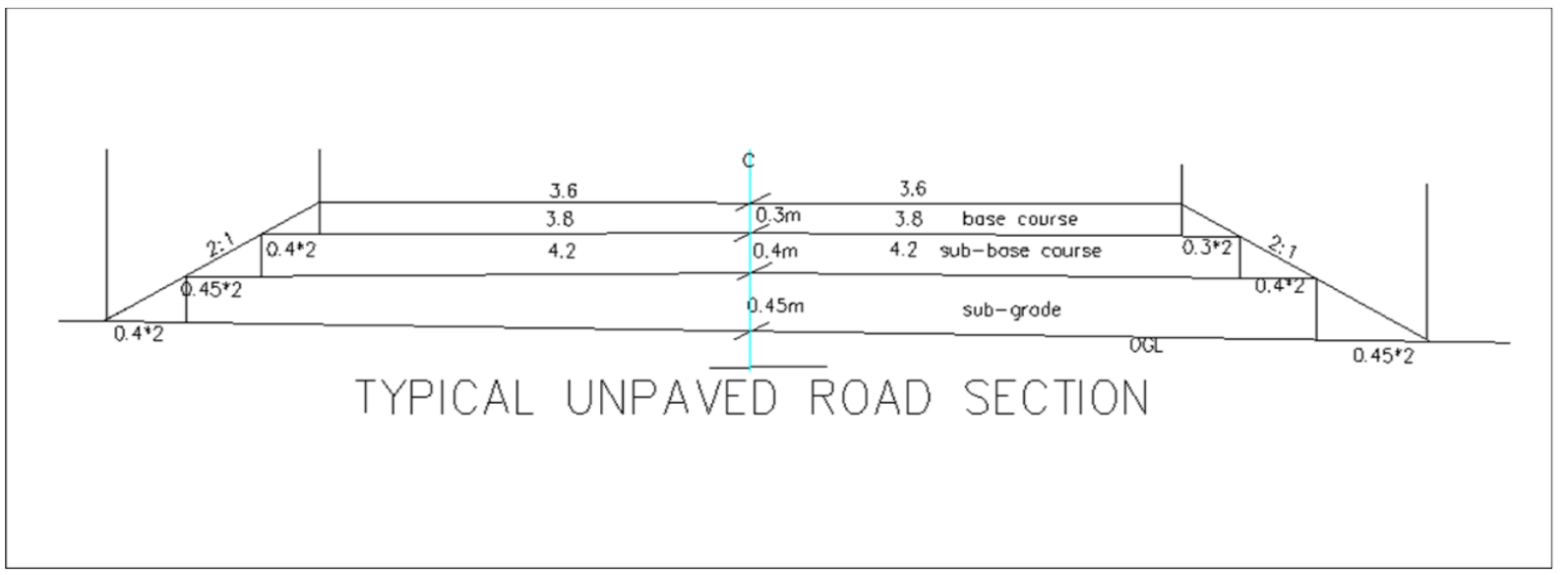

Figure 13: Typical unpaved road section for cost analysis

The road section selected assumed to be a uniform width throughout $1.0 \mathrm{~km}$; including dump truck loads of $14 \mathrm{~m}^{3}$ in a trip. In addition, $8 \%$ shrinkage factor and $12 \%$ loss in transportation and construction activities were assumed.

- The uniform selected road section $(\mathrm{L})=1 \mathrm{~km}$ or 1000.0 meters

- The upper width of the sub-base layer $\left(b_{1}\right)=8.4$ meters

- The lower layer of the sub-base layer $\left(b_{2}\right)=10.2$ meters

- The thickness of the sub-base layer $(\mathrm{h})=0.4$ meter

The area of a trapezoidal cross-section of the sub-base course layer becomes:

$$
\begin{aligned}
\mathrm{A} & =0.5^{*} 0.4 \mathrm{~m}(8.4 \mathrm{~m}+10.2 \mathrm{~m}) \\
& =3.72 \text { Sq.M }
\end{aligned}
$$

The shrinkage and loss factor $(f)=8 \%+12 \%=20 \%=0.2$

The total volume of material required and transported from production site to construction site including loss and shrinkage factor for $1 \mathrm{~km}$ road sub-base layer

$$
\begin{aligned}
\mathrm{V}_{\mathrm{T}} & =\mathrm{AL}(1+f) \\
& =3.72 \mathrm{~m}^{2 *} 1000 \mathrm{~m}(1.2) \\
& =4,464 \mathrm{Cu} . \mathrm{m}
\end{aligned}
$$


The total number of trips required to transport the material from the production site to construction site equals 319 total trips required. The transportation cost of materials for Sodo- Sawla road project, including fuel cost, loading \& unloading cost to transport $1 \mathrm{~km}$ becomes $100 \mathrm{ETB} / \mathrm{km}$. It was the blending technique applied for a specific project assumed as mixing at a construction site. Therefore, to transport the material to the construction site required a total trip of 319 trips (33.6\% $=107$ trips from $3.0 \mathrm{~km}$ (Suka) and $66.4 \%=212$ trips from $15.0 \mathrm{~km}$ (Mela), whereas the total volume of crushed aggregate came from the crusher site near Maze $(30 \mathrm{~km})$, and additional purchasing cost of $100 \mathrm{ETB} / \mathrm{m}^{3}$ was required.

\subsection{Cost Comparison}

The cost for the natural aggregates from quarry sites used to compare the crushed aggregate transportation cost and purchasing cost from MSEs. Thus, the total cost of mechanically stabilized material became $(107$ trips $* 3 \mathrm{~km} * 100 \mathrm{ETB} / \mathrm{km}=32,100 \mathrm{ETB}+212$ trips $* 15 \mathrm{~km} * 100 \mathrm{ETB} / \mathrm{km}$ $=318,000 \mathrm{ETB})=350,100 \mathrm{ETB} / \mathrm{km}$ and construction (mixing) cost of $150 \mathrm{ETB} / 100 \mathrm{~m}(1000)=$ $1500 / \mathrm{km}$. Hence, the total cost provided 350,100 ETB $/ \mathrm{km}+1500 \mathrm{ETB} / \mathrm{km}=351,600 \mathrm{ETB} / \mathrm{km}$.

The total cost of crushed aggregate material from the production site to construction site equals $\left[(319\right.$ trips $\left.* 30 \mathrm{~km} * 100 \mathrm{ETB} / \mathrm{km})+\left(100 \mathrm{ETB} / \mathrm{m}^{3} * 4,464 \mathrm{~m}^{3}\right)\right]=1,403,400 \mathrm{ETB}$.

When the results compared the crushed aggregate near the Maze crusher site, the purchased and transported cost with Mechanically stabilized natural gravel from Suka quarry sites (33.6\%), and from Mela (66.4\%), the cost of transportation, mixing \& purchasing was almost tripled. So, using mechanically stabilized natural gravel from Suka and Mela quarry sites indicated more economical for sub-base material of unpaved roads around Sawla town.

\section{Conclusion}

Based on the laboratory test results of this experiment, the following conclusions are drawn:

Scarcely of suitable materials had been a long concern, and this research study may be replenishing the problem. Based on the results, a better understanding of the geotechnical engineering properties of natural gravel soils of Goffa zone, Sawla area is very important. This will help augment the construction industries to satisfy the requirements of ERA standard specification, specifically in the construction of the sub-base course layer.

There were three (3) quarry sites considered for the research study. For Suka quarry sites, it was found out that the observed value of PI is $13 \%$, which was above the Upper Limit of the PI value of $12 \%$. The observed value of Gradation was below the lower Limit on most sieve sizes, including the observed value for LAA of $35.26 \%$, below $51 \%$. This means the soils, comprised of low resistance to abrasion. However, the computed CBR value was $34 \%$, which was above $30 \%$. It can be postulated that natural gravel soil from this quarry site is good for sub-base material.

For Mela quarry site, based on Laboratory test results, the observed PI value of $9 \%$ was within the Lower and Upper Limit of 6-12\%. All grain sizes observed above the maximum size per different sieve sizes, and Los Angeles Abrasion value was more than 51\%. It means the soil is Low 
resistance, and the CBR value indicated $28.9 \%$, which was below $30 \%$. This natural gravel was short to meet the minimum requirements as per ERA standard specifications.

Likewise, for Duza quarry site, the observed PI value of $23.90 \%$ was beyond the upper Limit, while all grain sizes were above the maximum sizes per different sieve sizes. The value for LAA of $78.34 \%$ beyond $51 \%$. This means the aggregates are not suitable for sub-base material alone.

Since the researcher has foreseen that there is a scarcity of suitable natural gravel soils for subbase material in the future, blending or mix proportion of samples extracted from Suka and Mela quarry site was the feasible approach. Based on the analyses, $33.6 \%$ of natural gravel soils form Suka quarry site, and $66.4 \%$ of natural gravel from the Mela quarry site are considered for the study. After mixing/blending of the natural gravel soils, the same engineering properties of soils computed to determine how much improvement of the quality of blended soils. Therefore, the following observed values were: PI is $9.52 \%$, and sizes of all particles are observed to be within the Limit. The Los Angeles Abrasion of 34.01 was below 51\%, which mean higher resistance, soil, while the CBR value was $40 \%$, which is above the minimum and could be very suitable for subbase material.

In mixing /blending natural gravel materials from Seka and Mela, it could be concluded that the mixed material improved the strength of sub-base materials of about $33.3 \%$. However, it must be understood that it must satisfy the requirements of the standard specification to perform the laboratory tests. This is the most important consideration in order to obtain a good quality of subbase materials for unpaved road construction in Goffa zone, Sawla area.

More so, the crushed aggregate near the Maze crusher site if purchased and transported, compared with Mechanically stabilized natural gravel from Suka quarry sites (33.6\%) plus Mela quarry site (66.4\%) the cost of transportation, mixing \& purchasing, is likely three times the cost of the blended aggregates. Therefore, using mechanically stabilized natural gravel from Suka and Mela quarry sites will provide more economical for sub-base material of unpaved roads around Sawla town.

\section{References}

[1] Trh 20 South Africa, (1990). The Structural Design, Construction, and Maintenance of Unpaved Roads Draft.

[2] J R Cook \& C S Gourley TRL Ltd, UK a Framework for the Appropriate Use of Marginal Materials.

[3] Team Leader, Central Laboratory Ethiopian Road Authority (November 2010). Experimental Treatment Options for Expansive Soils on Unpaved Roads in Ethiopia Addis Ababa.

[4] Berkshire Regional Planning Commission, Dunham Mall, Pittsfield, (MA2010). The Massachusetts Unpaved Roads BMP manual,

[5] Zikmund Rakowski, Jacek Kawale (1981). Mechanically Stabilized Layers in Road Construction Tensar International, UK, Technical University of Silesia.

[6] Yibas Mamuye, Emer Tucay Quezon, Anteneh Geremew (2018). Combined Effects of MolassesLime Treatment of Poor Quality Natural Gravel Materials Used for Sub-Base and Base Course Construction; GSJ Vol. 6(7), 621-633.

[7] Almaz Ejeta, Emer Tucay Quezon, Kabtamu Getachew (2017). Engineering Properties of Mechanically Stabilized Sub-base Material Using Natural Gravel around Jimma Quarry Sites for Unpaved Road Construction; GSJ Vol. 5(5), 93-104. 
[8] Department for International Development (DFID) (2000) Stabilized Sub-Bases for Heavily Trafficked Roads

[9] ERA (2002). Standard Technical Specification Sub-base Road Base and Gravel Wearing Course.

[10] AASHTO Standard Specification for Transportation Materials and Methods of Sampling and Testing.1993. (Twenty-first edition 2001 (Part 1).

[11] AASHTO. Standard Specification for Transportation Materials and Methods of Sampling and Testing.1993. (Twenty-first edition 2001 (Part 2)

[12] Poland. F. P. Henning, G. J. Giumarra and D. C. Roux (June 2008). Deterioration Modeling, Gravel Loss, Gravel Roads, Maintenance, Maintenance Guidelines, Shape Factor, Unsealed Roads.

[13] Rapid Response Research Service (June 2009). Environmental Considerations for Dust Control Measures,

[14] Department for International Development (DFID) (2000). Design of Stabilized Sub-Bases for Heavily Trafficked Roads

[15] Transport Research Laboratory, UK. (1982). International Road maintenance handbook. France, Germany and the United Kingdom. Volume II of IV unpaved road.

[16] Alemgena Alene ARAYA (2011). Characterization of Unbound Granular Materials for Pavements.

[17] Fed ERA (2011). The Democratic Republic Ethiopian Road Authority; Manual Low Volume Traffic.

[18] Ozark, Higrans office Blvasuite (2011). Better Unpaved Road for Nature and People.

[19] D. Jones, A. Rahim, S. Saadeh, and J.T. Harvey (May 4, 2012) Guidelines for stabilization of subgrade soil in California.

[20] ERA (2002). Pavement Design Manual Volume I-2002 (Flexible Pavements and Gravel Roads).

\footnotetext{
*Corresponding author.

E-mail address: ediredada@ gmail.com/quezonet09@ gmail.com
} 